\title{
An Assessment of the Managerial Skills and Professional Development Needs of Private Catholic Secondary School Administrators in Bangkok, Thailand
}

\author{
Samera Batao Ibay ${ }^{1} \&$ Mark Anthony Cenas Pa-alisbo ${ }^{1, *}$ \\ ${ }^{1}$ Faculty of Education, St. Theresa International College, Nakhon Nayok, Thailand \\ *Correspondence: Faculty of Education, St. Theresa International College, Ongkharak, Nakhon Nayok, Thailand. Tel: \\ 66-966-570-379. E-mail: markanthony@stic.ac.th
}

Received: February 7, 2020

Accepted: February 17, $2020 \quad$ Online Published: February 20, 2020

doi:10.5430/wje.v10n1p149

URL: https://doi.org/10.5430/wje.v10n1p149

\begin{abstract}
The knowledge and ability of the individuals in a managerial position are to fulfill some specific management activities or tasks. Managerial skills are important for many reasons. Being a manager in an educational setting is a position to act as an effective leader and problem-solver in many simple and complex situations. However, in Thailand, it was observed that some managerial skills need to improve their skills. School managers should strengthen and develop to manage effectively and efficiently.

This mixed research surveyed the managerial skills of the school administrators in terms of conceptual skills, human skills, and technical skills in selected private catholic secondary schools in Bangkok, Thailand. The respondents self-assessed their managerial skills in the form of a checklist, and to validate the results, interviews were conducted to determine the professional development needs according to the lowest items assessed by the school administrators. A questionnaire anchored on Robert Katz's theory of managerial skills and developed by Goodarzi (2002) was used to gather data.

With regards to the assessment of managerial skills' practice of the school administrators, most of them assessed themselves as very good in terms of conceptual skills, human skills, and technical skills. The professional development needs of the private catholic school administrators in terms of conceptual skills are the identification of informal organization, articulation of strategy, and ability of prediction. On the other hand, school administrators need training in controlling conflict, report generation, and official correspondence in terms of human skills. Finally, they need professional development in financial management, computer skill, and marketing in terms of technical skills.
\end{abstract}

Keywords: managerial skills, professional development needs, professional development plan, private catholic secondary school administrators

\section{Introduction}

\subsection{Background of the Problem}

Throughout one's career in education, professional development is required. According to Pinto (2018), it supports professionalism and provides equal opportunities for educators to gain and improve the knowledge and skills relevant to their job performance. Bush, Middlewood, and Briggs (2006), conducted a study of the impact of school leadership development: evidence from the new visions program for early headship, according to their study, leadership and management development is needed as it gradually becoming accepted in other countries but to meet the needs of school leaders and managers, training are significant to be appropriate and their one's career and to widen their educational system.

According to Nazari (2017), many researchers believed that leadership's new approaches can have a big impact on followers' attitudes and can increase the satisfaction and commitment of the employees. The study of Management skills tools for leadership imperatives in democracy conducted by Abbass (2012), skills in management are all-encompassing. To accomplish the vision and mission of organizations, managers required to have management 
skills as essential to them. They are obligatory as a part or element for efficiency and effectiveness in management.

In Thailand, Thai leadership is imperium in the Thai public sector. Thailand is one of the countries in Asian where the majority of people respect Buddhism as their respected religion. Harmony and peace are among the key aspects of Thai life. Managers in Thailand would like to take part in some community activities with their employees because they believe that through activities, they will have a deeper understanding of their employees do that the leader can also develop their team (Yukongdi, 2010).

The secondary school administrators in Bangkok, Thailand are an enthusiastically important role in ensuring that the systems are effectively and efficiently operating. They give a practical exhibition of a high level of outstanding in every field of education. They also ensure all teachers and staff are producing or create something towards a common goal and at the same time improving standards and circumstances and provide leadership as well as arranged optimistic visions for the future of the educational institutions they serve.

According to Goodarzi, Nazari, Ehsani (2012), in this modern world, managers could not be successful without knowing basic management skills. As a result, every manager should have excellent knowledge of their work environment. Therefore, the manager's performance is based on management skills. In the study of prioritizing managerial skills based on Katz's theory in physical education offices of universities in Iran, conducted by Afshari, Honari, Qafouri, Jabari, (2012), managerial skills are one of the reasons underlying managerial success. Management effectiveness and efficiency require managerial skills. Thus, these realities prompted the researcher to conduct the study.

\subsection{Related Literature}

One of the human social discussions is leadership. The successful existence of teamwork depends on proper and efficient management. To achieve their aim and hit the mutual objectives, efficient and effective leader for a group of people is needed (Moradi, Jafari, \& Omidi, 2013). According to Kheirdmand, Lotfi \& Etebarian (2012), an efficient manager must be expertise in the four skills, those are technical skill, cognitive skill, human skill and political skill. Managers and leaders must need to know management skills that can provide the proper context for the activities they do. Goodarzi, Nazari \& Ehsani (2012), in this modern world, no manager will be accomplished without having basic management skills. In other words, managers are required to have good knowledge of the dynamism of their work environment. Therefore, the efficiency and effectiveness of managers and leader's performances are based on management skills.

Nazari, Ghasemi \& Sohrabi, (2016) made proper planning necessary for effective athletic directors to improve communication and management skills in these organizations. Also, Goodarzi, Nazari \& Ehsani (2012) stated that managers who take into account the effective communication networks, and improve human skills, including improvement of communicational skills and management skills of the athletic managers, and explaining the relationship between them can improve the level of communication. Ultimately, this will lead to organizational effectiveness.

The guarantors of success or failures of any organization are the managers. Management quality at all levels indicates manager penetration and effectiveness. Organizational management and human resources management skills determine how well an organization operates. These skills are the ability to apply the technical knowledge and personal experience of a manager (Salehi \& Mohammadi, 2014). Human skills mean special abilities and qualities to control and manage oneself and others (Torki, Shouriche, \& Meshgati, 2011).

According to Reiitzug (2002), training is the traditional and still influential form of professional development. Grobler et al., (2002) stated that training includes direct instruction, skill demonstration with workshops and presentations. However, training involves instruction by an expert or experienced employee on the job processes in an organization. Cronje, De, Gawie \& Motlatla (2004) also stated that providing employees with knowledge, skills, values and atittudes to do a particular work effectively and efficiently.

In the theory of Katz's (1974), Skills of an Effective administrator: leadership development, the successful manager has triplet managerial skills these are: conceptual skills, human skills, and technical skills are developed separately. Accordingly, Daniel Katz and Robert Kahn (nd), management skills are divided into three major areas: technical, involving securities planning, organizing, human, it is dealing with human relationships and people skills. Motivating and moral skills, and conceptual, emphasizing knowledge and technical skills are related to the service of the organization. 


\section{Methods and Materials}

This research utilized mixed-method design in which the respondents self-assessed their managerial skills, and to validate the results, interviews were conducted to determine the professional development needs among the selected respondents from private catholic schools in Bangkok, Thailand. These served as bases for crafting a professional development plan for school administrators. One hundred (100) school administrators which comprised the school directors, assistant directors, principals, assistant principals, and department heads made up the sample of the study.

The questionnaires were based on the framework of Katz's managerial skills and developed by Goodarzi (2002). This includes conceptual skills, human skills, and technical skills. Conceptual skills were composed of 14 items, Human skills were composed of 17 items and Technical skills were 9 items. This questionnaire was translated into Thai and those items with the lowest mean scores were considered for validation and discussion. The quantitative data were processed and analyzed with the use of the Statistical Package for Social Sciences (SPSS). For the qualitative data, the interview responses were transcribed and categorized according to themes. Thematic analysis was used to interpret the data gathered through interviews.

\section{Results}

\subsection{The Assessment of Managerial Skills}

Concerning the assessment of managerial skills in terms of conceptual skills, human skills, and technical skills of the school administrators, they assessed themselves as very good. This means that the school administrators demonstrated a high level of proficiency in conceptual skills but still needs improvement on certain aspects. The table below illustrates the assessment of managerial skills of the school administrators as respondents of this study.

Table 1. The Assessment of the Managerial Skills in Terms of Conceptual Skills

\begin{tabular}{|c|c|c|c|c|}
\hline \multicolumn{2}{|r|}{ Conceptual Skills } & mean & s.d & Description \\
\hline 1) & Prioritizing in Organization & 4.12 & 0.700 & Very Good \\
\hline 2) & Discipline & 4.10 & 0.689 & Very Good \\
\hline 3) & Goal Making & 4.02 & 0.651 & Very Good \\
\hline 4) & Mental Ability & 3.98 & 0.816 & Very Good \\
\hline 5) & Time Management & 3.97 & 0.731 & Very Good \\
\hline 6) & Provident & 3.94 & 0.648 & Very Good \\
\hline 7) & Identification of Organizational Structure & 3.93 & 0.831 & Very Good \\
\hline 8) & Creativity & 3.92 & 0.761 & Very Good \\
\hline 9) & Comprehensive Planning & 3.91 & 0.698 & Very Good \\
\hline 10) & Multi-job & 3.89 & 0.723 & Very Good \\
\hline 11) & Recognition of Strength and Weakness & 3.86 & 0.725 & Very Good \\
\hline 12) & Evaluation of Planning Effectiveness & 3.73 & 0.839 & Very Good \\
\hline 13) & Identification of Informal Organization & 3.70 & 0.870 & Very Good \\
\hline 14) & Articulation of Strategy & 3.70 & 0.870 & Very Good \\
\hline 15) & Ability of Prediction & 3.66 & 0.699 & Very Good \\
\hline
\end{tabular}

Scale: 4.50 to 5.00 means Excellent; 3.50 to 4.49 signifies Very Good; 2.50 to 3.49 interprets Good; 1.50 to 2.49 means Fair; and lastly; 1.00 to 1.49 for Poor

These items were ranked from highest to lowest mean scores. The lowest mean scores are considered to be the professional development needs of the school administrators. These items were described as very good but not to the exceptional standard level. Two items that had the same mean scores of 3.70. These were the identification of informal organization and the articulation of strategy. Besides, the ability of prediction got the lowest mean score of 3.66. This means that school administrators need training in these areas. However, Xiaojuan (2010) found out that informal organization widely exists in social organization. The emergence of informal organization, internal rules and influential determination coupled with the right attitude, will bring out its positive role. Articulation of strategy setting up a strong underlying basis or principle on which to strengthen core processes, workforce, management systems, and organizational structure (Allison Partners, 2000). According to Eisenhardt \& Martin (2000), the skill to do to predict future circumstances and match the resource allocation will anticipate changes in a comfortable workplace. 
Table 2. The Assessment of the Managerial in Terms of Human Skills

\begin{tabular}{llccc}
\hline \multicolumn{1}{c}{ Human Skills } & Mean & Sd & Description \\
\hline 1) & Inter Organizational Relations & 4.05 & 0.796 & Very Good \\
2) & Good Temper & 4.00 & 0.853 & Very Good \\
3) & Communication Skills & 3.98 & 0.752 & Very Good \\
$4)$ & Motivating & 3.94 & 0.777 & Very Good \\
5) & Supervising & 3.90 & 0.810 & Very Good \\
6) & Informing & 3.90 & 0.745 & Very Good \\
7) & Individual Work & 3.88 & 0.856 & Very Good \\
$8)$ & Team Inspiration & 3.87 & 0.860 & Very Good \\
$9)$ & Doing Formalities & 3.85 & 0.783 & Very Good \\
10) & Conducting a Meeting & 3.84 & 0.837 & Very Good \\
11) & Disturbance Handle & 3.84 & 0.813 & Very Good \\
12) & Lecturing & 3.81 & 0.800 & Very Good \\
13) & Delegation of Authority & 3.80 & 0.816 & Very Good \\
14) & Negotiating & 3.76 & 0.767 & Very Good \\
$15)$ & Controlling Conflict & 3.73 & 0.777 & Very Good \\
$16)$ & Report Generation & 3.68 & 0.802 & Very Good \\
$17)$ & Official Correspondence & 3.65 & 0.702 & Very Good \\
\hline
\end{tabular}

Scale: 4.50 to 5.00 means Excellent; 3.50 to 4.49 signifies Very Good; 2.50 to 3.49 interprets Good; 1.50 to 2.49 means Fair; and lastly; 1.00 to 1.49 for Poor

In the aspect of human skills, the three lowest mean scores which were controlling conflict, report generation, and official correspondence are the areas that school administrators need training. According to Wahlstrom (n.d), managing conflict is important in many ways. Unmanaged conflict can have expensive legal consequences; a high level of negative conflict can cause employee dissatisfaction and decreased productivity. However, Wheadon (2014), also stated that report generation is important in management. Inefficient reporting processes that yield inaccurate and dated information normally cause more harm than good. Reporting is a necessity to produce timely and reliable information. Furthermore, Amadi (2019) defined official correspondence as an umbrella word to denote communication between persons, a person, and organizations, communication between two bodies, or communication between an organization and an individual.

Table 3. The Assessment of the Managerial Skills in Terms of Technical Skills

\begin{tabular}{clccc}
\hline Technical Skills & Mean & Sd & Description \\
\hline 1) & Operational Planning & 4.06 & 0.826 & Very Good \\
2) & Labor Division & 3.95 & 0.833 & Very Good \\
3) & Definition of Labor & 3.91 & 0.726 & Very Good \\
$4)$ & Evaluation of Performance & 3.87 & 0.774 & Very Good \\
5) & Absorption and Retention of Human force & 3.81 & 0.837 & Very Good \\
6) & Managerial Knowledge and Experience & 3.81 & 0.774 & Very Good \\
7) & Financial Management & 3.76 & 0.889 & Very Good \\
$8)$ & Computer Skill & 3.68 & 0.827 & Very Good \\
$9)$ & Marketing & 3.46 & 0.809 & Very Good \\
\hline
\end{tabular}

Scale: 4.50 to 5.00 means Excellent; 3.50 to 4.49 signifies Very Good; 2.50 to 3.49 interprets Good; 1.50 to 2.49 means Fair; and lastly; 1.00 to 1.49 for Poor

In the aspect of technical skills, the three lowest mean scores that school administrators' needs pieces of training were financial management, computer skill, and marketing. According to Brealey, Myers, Allen (2006), supervising working capital achieving and effectively, the need for businesses to focus their attention on the four short term assets. It includes accounts receivables, inventories, cash, and short term securities. However, Sharma (2019) defined computer skills as everyday life in today's generation. According to her, without the use of the computer, internet online and or offline business, educational services, and many other fields or professions it's very difficult or impossible to do daily life works. Kotler and Keller (2006), defined marketing as a managerial process in which every 
person and group can acquire what they need.

\subsection{The Professional Development Needs}

The professional development needs were based on the three lowest mean scores in each category and were conducted through the interview assessed by the school administrators. These items were as follows:

\subsubsection{Conceptual Skills}

\subsubsection{Identification of Informal Organization}

The researcher asked the question of the ten selected school administrators. What specific training do you need in order to strengthen your skill in the identification of informal organization? ${ }^{1 .}$ In order to improve the skill in terms of identification of informal organization, I think training on empowering and obtaining the trust of employees is important because, in this way, we can gain the empathy of the employees. ${ }^{2}$ Just be friendly with the staff, teachers, and other employees are the best way to strengthen this skill. ${ }^{3 .}$ Personal attitudes, likes, and dislikes should practice knowing. Knowing employees well leads to a healthy work culture. When employees know each other well, it will lessen the fighting and criticizing their fellow workers. Conflicts and misunderstandings not only spoil the ambiance in the workplace but also increase the stress levels of individuals. ${ }^{4}$ Training on how to know the employees in terms of what they want. Managers are required to know whether their employees are happy with their jobs or not. ${ }^{5}$. Training on interpersonal skills is important such as being able to communicate properly. ${ }^{6 .}$ I think training in interpersonal relationships is important it helps to develop and foster strong working relationships among employees. 7. For me, in order to improve this skill, strong relationships with each other are important, contribute to the increasing team and organizational productivity. ${ }^{8}$. Understanding individuals in the workplace. ${ }^{9 .}$ Training on interpersonal relationships such as promote a positive work environment. A positive work environment reduces stress, promotes creativity, and helps keep employees productive. ${ }^{10}$ I think the best way to improve it is to be friendly with the staff, teachers, and other employees of the school so that they can express their own ideas for the improvement of the school.

\subsubsection{Articulation of Strategy}

The researcher asked the ten selected school administrators. What specific training do you need to strengthen your skill in articulation of strategy? ${ }^{1 .}$ Training on effective strategies such as involving the whole organization in decision-making. ${ }^{2}$ Good strategic management training is important to sharpen the leadership skills to meet at the challenges of strategy execution and managing the team and organization to realize the goals of the school. ${ }^{3}$. Focus on student achievement, and practice more on school improvement. ${ }^{4}$. Training on effective strategies such as selecting, developing, improving, and sustaining the school and its staff's ability to implement an intervention as intended to benefit students effectively and efficiently. ${ }^{5}$ Training on Instructional leadership is important. Teaming up with leadership is a key to obtain a thriving organization. ${ }^{6}$ I think training on instructional leadership is needed because instructional leadership is the key to the school improvement process and its effectiveness to students. It cultivates the implementer's mindset, which is focus, discipline, and accountability within every school administrator, and see that concrete actions are taken toward goals every day. ${ }^{7}$ Build an effective instructional coaching program for all educators. ${ }^{8}$. Widening the concerns of the secondary department on academic activities, for me, international research training/seminars/workshops on trends and issues of English academic development of non-speakers of English. ${ }^{9}$ Training and seminars on strategic planning for school administrators. ${ }^{10}$. Training on strategic thinking concepts is needed.

\subsubsection{Ability of Prediction}

The researcher asked the ten selected school administrators. What specific training do you need to strengthen your skill in ability of prediction? ${ }^{1 .}$ Training on a cognitive ability such as the core skills that the brain uses to think, read, and learn, remember, reason and pay attention. ${ }^{2}$ Training on collaboration within the school institution. ${ }^{3 \cdot}$ Make a long-term plan and think about the advantage and disadvantages of the plan. ${ }^{4}$ Training/seminar on predictive analytics for school administrators. ${ }^{5}$. Training, seminars and workshops on personnel management, administrative skills on academics, and technology - computer literacy to help predict the possible output of the plan. ${ }^{6}$. Training on making a long term plan. When you know how to make a long-term plan, you can also foresee the expected output. ${ }^{7}$. Training, seminars to improve cognitive ability that includes strengthening the listening skill. ${ }^{8}$ Seminar-workshop on making a long- term plan for school administrators to foresee the expected output of the school plans. ${ }^{9}$. Seminars, trainings and workshops on ability to predict the positive and negative output of the school plans for school administrators. ${ }^{10 .}$ Cognitive trainings for school administrators. 


\subsubsection{Human Skills}

\subsubsection{Controlling Conflict}

The researcher asked the respondents. What specific training do you need to strengthen your skill in controlling conflict? ${ }^{1 .}$ Training on understanding human behavior. Every school administrator should know the behavior of his/her employees and understand other's perceptions and expectations. ${ }^{2}$. Training on identifying the barriers that exist outside and inside of the school as much as possible. ${ }^{3 .}$ Training on how to handle conflict and Training on Leadership strategies are needed. ${ }^{4}$. In any workplace, we cannot avoid conflicts. However, I think, every school administrator or manager should have training or seminar on handling people's behavior effectively. ${ }^{5}$ Leadership and Social training are needed to enhance getting along with the staff and personnel and improving the social relationship in the administration. ${ }^{6 .}$ Communicate respectfully. In Thailand, respect each other is very important especially as a school administrator. When everyone is respecting each other, the school will be more peaceful and conflict-free. ${ }^{7}$ Seminar-workshop on how to handle conflict. ${ }^{8}$. I think seminars/workshops/training on conflict management is needed. ${ }^{9}$ Every school administrator should learn and train on how to handle conflict. ${ }^{10}$. For me, to strengthen this skill, we need to train or have a seminar-workshop on conflict management. In this way, it can help us to improve our skills in controlling conflict.

\subsubsection{Report Generation}

The researcher asked the ten selected school administrators. What specific training do you need to strengthen your skill in report generation? ${ }^{1}$. Training on how to easily create effective reports that lead to action. ${ }^{2}$. Training on having a self-confidence to express ideas that leads for the improvement of the school. ${ }^{3 .}$ Training on effective research. ${ }^{4}$. Set report objectives and select the most appropriate data. ${ }^{5 .}$ Training on Research used in enhancing reports containing reliable and along with the global trends. ${ }^{6}$. Train to ask for clarification. I want everyone to feel free to clarify whenever they want ${ }^{7}$ I think training or seminar-workshop can be a solution to improve or to strengthen report generation. ${ }^{8}$. For me, every school administrator should learn and train on effective research, so that they will know how to get reliable resources for the report generation. ${ }^{9}$. in report generation, I think the best way to improve this, is to have a seminar-workshop on reporting. ${ }^{10}$. Training on improving communication is important. Because poor communication is a problem. Sometimes those using reports never talk directly to those who create them.

\subsubsection{Official Correspondence}

The respondents were asked the question: What specific training do you need to strengthen your skill in official correspondence? ${ }^{1}$ Being a school administrator should be able to write specially in English. I think the seminar for writing in English can help to develop. Because some the school administrators cannot write in English here in Thailand. ${ }^{2}$ Have a seminar/workshop on how to write a formal letter especially in English. In Thailand, most of the school administrators are not good in English writing. ${ }^{3 .}$ Have a seminar/workshop on how to write in English. Not all school administrators can write in English here in Thailand. Also, providing the finished product of the letter is easy to read and has a positive impact. ${ }^{4}$ Have a seminar on effective writing. Learn how to write a clear purpose statement that relates to grammar and composition. ${ }^{5 .}$ Seminar/Workshop on Business and Technical writing. ${ }^{6 .}$ Understand your readers; identify different structures in writing, and how to choose the most effective one/s to achieve the purpose. ${ }^{7}$. Training on improving report writing and improving English grammar punctuation and proofreading skills. ${ }^{8}$ Train to understand the audience. ${ }^{9}$. For me, to improve this skill, we need to train in effective writing skills because we may have to write different kinds of business letters. ${ }^{10}$. Training on research is a way to improve official correspondence.

\subsubsection{Technical Skills}

\subsubsection{Financial Management}

The respondents were asked the question: What specific training do you need to strengthen your skill in financial management? ${ }^{1}$. Training on fundamentals of financial management. ${ }^{2}$. Training on monitoring the financial position of the school. ${ }^{3}$ Have a seminar-workshop on the strategic and operational role of the finance function for school administrators. ${ }^{4}$. Income Generating Project is also a need to improve one's resourcefulness in augmenting expenditures beyond budget allocations. ${ }^{5}$. Have a clear plan for the school is important. For me, school administrators are required in this area. ${ }^{6}$. Training on basic financial statements. School administrators should be familiar with the basic financial statements prepared for external users and what information is presented in each statement. ${ }^{7}$. Training on budget preparation is needed. School administrators should know to prepare a departmental budget, a quantification of the resources that required achieving the objectives and action plans for the next school year. ${ }^{8}$. For me, training on variance analysis can help to improve this skill. Everyone should know how to analyze 
the variances against budget. ${ }^{9}$. Training, seminars or workshops on financial analysis of capital investments and strategic initiatives can be an opportunity for every school administrator. ${ }^{10}$. Training on making a plan that includes financial management.

\subsubsection{Computer Skills}

The respondents were asked the question: What specific training do you need to strengthen your skill in computer skill? ${ }^{1}$. Familiarize and understand how computers and internet works. Before you learn any specialized technical skills, at the very least you need a fundamental understanding of what a computer it is and how it works. In some cases, it can be helpful to learn how the internet works, too. ${ }^{2}$ Read technical books. One of the best ways to improve technical skills is by reading books or have a seminar/workshop on how to use a computer. ${ }^{3}$ Have a seminar/workshop on how to use a computer and how it works. ${ }^{4}$ Seminar/workshop on computer skills such as the use of internet and email, computers, word processing, graphics and multimedia, and spreadsheets that are useful for school administrators. ${ }^{5}$ An administrator has to be technologically advanced to facilitate his/her transactions or encounter with his/her staff personnel. Hence, Excel, SPSS, and social media are needed. ${ }^{6}$ Apply the knowledge and get hands-on practice. ${ }^{7}$. Training on essential internet skills, such as email, web browsing and searching. ${ }^{8}$ take classes on computer literacy. ${ }^{9}$ embrace a variety of software. General software productivity improves with breadth of experience, so use many different software programs -online or offline to improve the overall ability to get things done through software. ${ }^{10}$. Learn to program. For me, programming is the art of instructing a computer to perform the task. The key to accomplishing this feat is learning to think like a computer.

\subsubsection{Marketing}

The respondents were asked the question: What specific training do you need to strengthen your skill in marketing? ${ }^{1 .}$ Learn to have strong communication with the parents of the students. For me, school administrators should learn the marketing tactic. ${ }^{2}$ I think training on communication skills is important to develop because if you know how to communicate effectively it will lead you to be a good marketing too. ${ }^{3}$. Learn to be an excellent public speaker. Learning how to speak effectively will help in ways you could be. ${ }^{4}$. Attend a time-management course. Knowing how to use time wisely, is one of the important things that every school administrator should do in marketing because sometimes, success guaranteed if you know how to pay attention to the amount of time you spend on things. 5. School Campaign Training, Social Media Training, and Advertisement Training to improve student enrollees. ${ }^{6 .}$ Train to reach out to the stakeholders on social. Promote blog posts and videos on Facebook, YouTube, etc. to extend your reach. ${ }^{7}$ Seminar-workshop on marketing. Market to high-performing students. marketing to students can feel a bit icky, but the reality is it's something you'l likely have to do. ${ }^{8}$. Training on organize design assets. The design assets are the core of the marketing materials. ${ }^{9 .}$ Improve the website experience of the school. Have a great opportunity to provide a god experience, leaving the parents with a positive impression. ${ }^{10 .}$ Training, seminars and workshops on the advertisement.

\subsection{Professional Development Plan}

Based on the three lowest mean scores in each category, the researcher identified the professional development needs of school administrators. The needs were validated through the conduct of interviews as bases for proposing a professional development plan. The said plan is divided into three parts according to each category. Each part is composed of the general goal, specific objectives, proposed activities/programs, strategy, timeline, person/s involved, resources, and expected outcome. The contents covered in the professional development plan were based on the consolidated results of the interviews conducted to selected respondents of the study. 
Table 4. Professional Development Plan in Terms of Conceptual Skills

Goal 1: To improve the conceptual skills practice of secondary school administrators

\begin{tabular}{|c|c|c|c|c|c|c|}
\hline \multicolumn{7}{|c|}{ Identification of Informal Organization } \\
\hline $\begin{array}{l}\text { Specific Objectives } \\
\text { At the end of the } \\
\text { training, the } \\
\text { participants will be } \\
\text { able to: }\end{array}$ & $\begin{array}{l}\text { Proposed } \\
\text { Activities/ } \\
\text { Programs }\end{array}$ & Strategy & Timeline & $\begin{array}{l}\text { Person/s } \\
\text { Involved }\end{array}$ & $\begin{array}{l}\text { Resources } \\
\text { Needed }\end{array}$ & Expected Outcome \\
\hline $\begin{array}{l}\text {-strengthen their } \\
\text { interpersonal } \\
\text { relationships in the } \\
\text { organization }\end{array}$ & $\begin{array}{l}\text {-Teambuilding } \\
\text { Activity }\end{array}$ & $\begin{array}{l}\text {-Group } \\
\text { Dynamics }\end{array}$ & $\begin{array}{c}1^{\text {st }} \\
\text { Semester, } \\
2020\end{array}$ & $\begin{array}{l}\text { School } \\
\text { Administrators } \\
\text { and Teachers }\end{array}$ & $\begin{array}{l}\text {-Financial } \\
\text { Resources } \\
\text { /Budget }\end{array}$ & $\begin{array}{l}\text {-Strengthened the } \\
\text { interpersonal } \\
\text { relationships in the } \\
\text { organization. }\end{array}$ \\
\hline $\begin{array}{l}\text {-build trust and } \\
\text { cooperation among } \\
\text { members of the } \\
\text { organization }\end{array}$ & $\begin{array}{l}\text {-Training on } \\
\text { Enhancing } \\
\text { Interpersonal } \\
\text { Relationship in the } \\
\text { Organization. }\end{array}$ & $\begin{array}{l}\text {-Games } \\
\text {-Practical } \\
\text { Activities }\end{array}$ & & & -Materials & $\begin{array}{l}\text {-Built trust and } \\
\text { cooperation among } \\
\text { members of the } \\
\text { organization }\end{array}$ \\
\hline \multicolumn{7}{|c|}{ 2) Articulation of Strategy } \\
\hline $\begin{array}{l}\text { - master and apply } \\
\text { effective decision } \\
\text { making strategies }\end{array}$ & $\begin{array}{l}\text {-Training on } \\
\text { Effective } \\
\text { Decision-Making } \\
\text { Strategies }\end{array}$ & $\begin{array}{l}\text {-Identify the } \\
\text { possible } \\
\text { consequences } \\
\text {-Evaluating the } \\
\text { desirability of } \\
\text { each } \\
\text { consequence }\end{array}$ & $\begin{array}{c}2^{\text {nd }} \\
\text { Semester, } \\
2020\end{array}$ & $\begin{array}{c}\text { School } \\
\text { Administrators }\end{array}$ & $\begin{array}{l}\text {-Financial } \\
\text { Resources } \\
\text { /Budget }\end{array}$ & $\begin{array}{l}\text {-Applied Effective } \\
\text { Decision-making } \\
\text { strategies }\end{array}$ \\
\hline $\begin{array}{l}\text { - gain effective skills } \\
\text { in Instructional } \\
\text { Leadership }\end{array}$ & $\begin{array}{l}\text {-Training on } \\
\text { Instructional } \\
\text { Leadership }\end{array}$ & $\begin{array}{l}\text {-Assessing the } \\
\text { likelihood of } \\
\text { each } \\
\text { consequence } \\
\text {-Make a choice } \\
\text { using a decision } \\
\text { rule } \\
\text {-Make a choice } \\
\text { using a decision } \\
\text { rule }\end{array}$ & & $\begin{array}{l}\text { Invited } \\
\text { Speaker }\end{array}$ & -Materials & $\begin{array}{l}\text {-Gained effective } \\
\text { skills in } \\
\text { Instructional } \\
\text { Leadership }\end{array}$ \\
\hline \multicolumn{7}{|c|}{ 3) Ability of Prediction } \\
\hline $\begin{array}{l}\text {-develop critical and } \\
\text { creative thinking } \\
\text { skills. }\end{array}$ & $\begin{array}{l}\text {-Training/ } \\
\text { Workshop on } \\
\text { School } \\
\text { Development } \\
\text { Planning }\end{array}$ & $\begin{array}{l}\text {-Determining } \\
\text { and setting } \\
\text {-make a realistic } \\
\text { objectives }\end{array}$ & $\begin{array}{l}\text { Summer, } \\
2020\end{array}$ & $\begin{array}{c}\text { School } \\
\text { Administrators }\end{array}$ & $\begin{array}{l}\text {-Financial } \\
\text { Resources } \\
\text { /Budget }\end{array}$ & $\begin{array}{l}\text { Developed their } \\
\text { critical and creative } \\
\text { thinking skills. }\end{array}$ \\
\hline $\begin{array}{l}\text {-formulate a strategic } \\
\text { plan for their school. }\end{array}$ & $\begin{array}{l}\text {-Training on } \\
\text { Strategic Planning }\end{array}$ & $\begin{array}{l}\text {-Time frames } \\
\text { for the school } \\
\text {-Group } \\
\text { Discussion } \\
\text {-Practical } \\
\text { Activity }\end{array}$ & & $\begin{array}{l}\text { Community/ } \\
\text { Stakeholders }\end{array}$ & -Materials & $\begin{array}{l}\text {-Formulated a } \\
\text { strategic plan for } \\
\text { the school. }\end{array}$ \\
\hline
\end{tabular}


Table 5. Professional Development Plan in Terms of Human Skills

Goal 2: To improve the human skills practice of the secondary school administrators.

\begin{tabular}{|c|c|c|c|c|c|c|}
\hline \multicolumn{7}{|c|}{ 1) Controlling Conflict } \\
\hline $\begin{array}{l}\text { Specific Objectives } \\
\text { At the end of the training, } \\
\text { the participants will be } \\
\text { able to: }\end{array}$ & $\begin{array}{l}\text { Proposed } \\
\text { Activities/ } \\
\text { Programs }\end{array}$ & Strategy & Timeline & $\begin{array}{l}\text { Person's } \\
\text { Involved }\end{array}$ & $\begin{array}{l}\text { Resources } \\
\text { Needed }\end{array}$ & Expected Outcome \\
\hline $\begin{array}{l}\text {-develop problem solving } \\
\text { and decision making } \\
\text { abilities. }\end{array}$ & $\begin{array}{l}\text {-Training on } \\
\text { Conflict } \\
\text { Management }\end{array}$ & $\begin{array}{l}\text {-Review the } \\
\text { six elements } \\
\text { to be able to } \\
\text { analyse } \\
\text { conflict well } \\
\text { by Dana } \\
\text { (2001). }\end{array}$ & $\begin{array}{l}1^{\text {st }} \\
\text { Semester, } \\
2021\end{array}$ & $\begin{array}{l}\text { School } \\
\text { Administrators }\end{array}$ & $\begin{array}{l}\text {-Financial } \\
\text { Resources } \\
\text { /Budget }\end{array}$ & $\begin{array}{l}\text {-Developed } \\
\text { problem solving } \\
\text { and decision } \\
\text { making abilities. }\end{array}$ \\
\hline $\begin{array}{l}\text {-enhance practical conflict } \\
\text { resolution techniques and } \\
\text { strategies that } \\
\text { administrators can } \\
\text { effectively utilize when } \\
\text { managing conflict in the } \\
\text { workplace. }\end{array}$ & $\begin{array}{l}\text {-Training on } \\
\text { Conflict } \\
\text { Resolution }\end{array}$ & $\begin{array}{l}\text {-Presentation, } \\
\text { individual } \\
\text { reflection and } \\
\text { pairs, } \\
\text { exercise, and } \\
\text { group review. }\end{array}$ & & Guest Speaker & & $\begin{array}{l}\text {-Enhanced } \\
\text { practical conflict } \\
\text { resolution } \\
\text { techniques and } \\
\text { strategies that } \\
\text { administrators can } \\
\text { effectively utilize } \\
\text { when managing } \\
\text { conflict in the } \\
\text { workplace. }\end{array}$ \\
\hline \multicolumn{7}{|c|}{ 2) Report Generation } \\
\hline $\begin{array}{l}\text {-upgrade research skills of } \\
\text { the teachers and } \\
\text { administrators. }\end{array}$ & $\begin{array}{l}\text {-Training on } \\
\text { Writing } \\
\text { Classroom-Based } \\
\text { Research }\end{array}$ & $\begin{array}{l}\text {-Stating } \\
\text { problems of } \\
\text { research. }\end{array}$ & $\begin{array}{c}\text { 2nd } \\
\text { Semester, } \\
2021\end{array}$ & $\begin{array}{c}\text { School } \\
\text { Administrators } \\
\text { and Teachers. }\end{array}$ & $\begin{array}{c}\text { Financial } \\
\text { Resources } \\
\text { /Budget }\end{array}$ & $\begin{array}{l}\text {-Enhanced research } \\
\text { skills of the } \\
\text { teachers and } \\
\text { administrators }\end{array}$ \\
\hline $\begin{array}{l}\text {-enhance writing of school } \\
\text { reports. }\end{array}$ & $\begin{array}{l}\text {-Training on } \\
\text { Effective Writing } \\
\text { of School Reports } \\
\text { (Enhancement } \\
\text { Training) }\end{array}$ & $\begin{array}{l}\text {-Presentation } \\
\text { of school } \\
\text { writing } \\
\text { reports. }\end{array}$ & & Guest Speaker & -Materials & $\begin{array}{l}\text {-Enhanced writing } \\
\text { of school reports. . }\end{array}$ \\
\hline \multicolumn{7}{|c|}{ 3) Official Correspondence } \\
\hline $\begin{array}{l}\text {-develop effective } \\
\text { communication strategies } \\
\text { for a variety of audiences. }\end{array}$ & $\begin{array}{l}\text {-Training on } \\
\text { Technical Writing } \\
\text { in English } \\
\text { (Communications } \\
\text {, Memos, etc.) }\end{array}$ & $\begin{array}{l}\text {-Demonstrate } \\
\text { practical } \\
\text { methods to } \\
\text { help create } \\
\text { better } \\
\text { documents. }\end{array}$ & $\begin{array}{l}\text { Summer, } \\
2021 \text {. }\end{array}$ & $\begin{array}{c}\text { School } \\
\text { Administrators }\end{array}$ & $\begin{array}{c}\text {-Financial } \\
\text { Resources } \\
\text { /Budget }\end{array}$ & $\begin{array}{l}\text { Developed } \\
\text { effective } \\
\text { communication } \\
\text { strategies for a } \\
\text { variety of } \\
\text { audiences. }\end{array}$ \\
\hline $\begin{array}{l}\text {-strengthen practical } \\
\text { methods to help create } \\
\text { better documents. }\end{array}$ & & $\begin{array}{l}\text {-Review the } \\
\text { essential skills } \\
\text { of effective } \\
\text { technical } \\
\text { writing. }\end{array}$ & & Guest Speaker & & $\begin{array}{l}\text { Strengthened } \\
\text { practical methods } \\
\text { to help create better } \\
\text { documents. }\end{array}$ \\
\hline $\begin{array}{l}\text {-provide tools and } \\
\text { techniques for } \\
\text { specification and report } \\
\text { writing. }\end{array}$ & & $\begin{array}{l}\text {-Practical } \\
\text { Activity }\end{array}$ & & & & $\begin{array}{l}\text { Developed tools } \\
\text { and techniques for } \\
\text { specification and } \\
\text { report writing. }\end{array}$ \\
\hline
\end{tabular}


Team building is an important factor in any environment; its focus is to specialize in bringing out the best in a team to ensure self- development, positive communication, leadership skills and the ability to work closely together as a team to solve problems. In the absence of teams, employees are limited to individual efforts alone but with teambuilding, workgroups evolve into cohesive units and share expectations for accomplishing group tasks, added to trust and support for one another and respect for individual differences (Fapohunda, 2013). To improve the conceptual skills in terms of identification of informal organization, enhancing interpersonal relationships can be one of the solutions. Valued interpersonal relationships can influence organizational outcomes by increasing institutional participation, establish supportive and innovative climates, increasing organizational productivity and indirectly reducing the intent to turnover (Berman et al., 2002; Crabtree, 2004; Ellingwood, 2004; Song and Olshfski, 2008).

The skills that are considered vital to efficient and effective decision making were based on a normative model of decision making, which prescribes how decisions should be made. These skills consist of identifying the possible options; identifying the possible consequences that follow from each option; evaluating the desirability of each consequence; assessing the likelihood of each consequence and making a choice using a decision rule (Gilboa, 2011). In order to articulate a strategy for the school, instructional leadership must be practice. Visibly, the leader heads the organization and exerts its image. In this is way, specific power dynamics emerge between the members of the organization managed by the denominated leader (Harris, 2014; Piot \& Kelchtermans, 2016). In this way, leadership must be implemented from the heart of the school, being considered as a quality that includes the educational community (Gronn, 2002; Gronn, 2009).

School development planning requires technical knowledge and skill for its execution. For example, determining and setting, realistic objectives, time-frames, performance indicators, and costing are some of the activities that require knowledge and skill to determine. The success of the school development planning process is, therefore, a function of the understanding of its intentions, as well as being initiated by the school community. In this way, schools will be in a position to self-audit in a realistic manner which focuses on schools' own improvement, innovation and change needs (Xaba, 2006). On the other hand, the concept of strategic planning is an instrument that allows making long-term plans in consideration of the risks and opportunities faced by the organization and improving efficiency by acting in the line with these plans (Hall, 2013).

School managers and leaders need to understand what is entailed in conflict management and need high conflict competence to be able to be effective in their schools. When conflict management has determined and defined the nature of the conflict in a conflict situation, they try and find ways of resolving it (Msila, 2012). Furthermore, Dana (2001) stated that leaders need to comprehend structure to be able to analyze conflicts well. They were six parts of conflict structure that administrators can pay attention to; interdependency, number of interested parties, constituent, negotiator authority, critical urgency, communication channel. Dana (2001) perceives that these six dimensions as elements that are necessary to be able to analyze conflict well.

Writing must be deemed an essential part of the school experience while developing curriculum, selecting instructional materials, prioritizing PD opportunities, allocating time and effort for instruction, and weighing student outcomes. Writing instruction and practice should occur every day and in all subjects to gain confidence and competence with writing for varied purposes and audiences (Graham \& Bolinger et al., 2012).

Technical writing in English serves as an essential tool in communicating or conveying one's ideas, views, observations, instructions, and suggestions in a more logical and technical manner. Professionals need to have good technical writing skills in the preparation of reports, presentations, documentation, etc. Technical writing in English is used for a specific purpose, and hence it needs to be precise, relevant, and without redundancy (Dubey, 2018). 
Table 6. Professional Development Plan in Terms of Technical Skills

GOAL 3: To improve the technical skills practice of secondary school administrators

\begin{tabular}{|c|c|c|c|c|c|c|}
\hline \multicolumn{7}{|c|}{ 1) Financial Management } \\
\hline Specific Objectives & Proposed & Strategy & Timeline & Person's & Resources & Expected Outcome \\
\hline $\begin{array}{l}\text { At the end of the } \\
\text { training, the participants } \\
\text { will be able to: }\end{array}$ & $\begin{array}{l}\text { Activities/ } \\
\text { Programs }\end{array}$ & & & Involved & Needed & \\
\hline $\begin{array}{l}\text {-enhance financial } \\
\text { decisions and resolving } \\
\text { financial problems. }\end{array}$ & $\begin{array}{l}\text {-Seminar/Worksh } \\
\text { op on } \\
\text { Fundamentals of } \\
\text { Financial } \\
\text { Management and } \\
\text { Financial } \\
\text { Strategies. }\end{array}$ & $\begin{array}{l}\text {-Financial } \\
\text { Discussion }\end{array}$ & $\begin{array}{c}1 \text { st } \\
\text { Semester, } \\
2022\end{array}$ & $\begin{array}{l}\text { School } \\
\text { Administrators }\end{array}$ & $\begin{array}{l}\text { Financial } \\
\text { Resources/ } \\
\text { Budget/ } \\
\text { Materials }\end{array}$ & $\begin{array}{l}\text {-Enhanced } \\
\text { financial decisions } \\
\text { and resolving } \\
\text { financial problems. }\end{array}$ \\
\hline $\begin{array}{l}\text {-encourage strategic } \\
\text { prioritization of } \\
\text { expenditures for } \\
\text { programs and projects. }\end{array}$ & $\begin{array}{l}\text {-Investment } \\
\text { Strategy } \\
\text { Management }\end{array}$ & $\begin{array}{l}\text {-Sharing of } \\
\text { Thoughts and } \\
\text { Ideas Activity }\end{array}$ & & School Finance & & $\begin{array}{l}\text { Contributed to the } \\
\text { effective financial } \\
\text { management of the } \\
\text { organizations. }\end{array}$ \\
\hline $\begin{array}{l}\text {-encourage technical } \\
\text { efficiency in the use of } \\
\text { budget resources as well } \\
\text { as accountability for } \\
\text { their use by ensuring } \\
\text { that resources once } \\
\text { allocated are used in an } \\
\text { effective, efficient and } \\
\text { transparent way. }\end{array}$ & $\begin{array}{l}\text {-Financial } \\
\text { Provision }\end{array}$ & $\begin{array}{l}\text {-Practical } \\
\text { Activity }\end{array}$ & & Guest Speaker & & $\begin{array}{l}\text { Able to evaluate } \\
\text { alternative courses } \\
\text { of action and } \\
\text { identify the most } \\
\text { effective choices } \\
\text { with regard to } \\
\text { future } \\
\text { improvement }\end{array}$ \\
\hline \multicolumn{7}{|c|}{ 2) Computer Skills } \\
\hline $\begin{array}{l}\text {-enhance the use of } \\
\text { various applications in } \\
\text { Microsoft Excel, } \\
\text { Spreadsheets, and SPSS. }\end{array}$ & $\begin{array}{l}\text {-Training on } \\
\text { Microsoft Excel, } \\
\text { Spreadsheets, } \\
\text { SPSS }\end{array}$ & $\begin{array}{l}\text {-Actual use of } \\
\text { Microsoft } \\
\text { Excel, } \\
\text { Spreadsheets, } \\
\text { SPSS. }\end{array}$ & $\begin{array}{l}\text { 2nd } \\
\text { Semester, } \\
2022\end{array}$ & $\begin{array}{c}\text { School } \\
\text { Administrators }\end{array}$ & $\begin{array}{c}\text {-Financial } \\
\text { Resources/B } \\
\text { udget }\end{array}$ & $\begin{array}{l}\text { Enhanced the use } \\
\text { of various } \\
\text { applications } \\
\text { in Microsoft Excel, } \\
\text { Spreadsheets, and } \\
\text { SPSS. }\end{array}$ \\
\hline $\begin{array}{l}\text {-introduce different } \\
\text { online resources to } \\
\text { determine whether their } \\
\text { usage is fair use or } \\
\text { requires prior written } \\
\text { permission. }\end{array}$ & $\begin{array}{l}\text {-Training on } \\
\text { Proper use of } \\
\text { Social } \\
\text { Networking Sites } \\
\text { (Acedemic-related } \\
\text { ) }\end{array}$ & $\begin{array}{l}\text {-Practical } \\
\text { Activity }\end{array}$ & & Teachers & -Materials & $\begin{array}{l}\text { Introduced } \\
\text { different online } \\
\text { resources to } \\
\text { determine whether } \\
\text { their usage is fair } \\
\text { use or requires } \\
\text { prior written } \\
\text { permission. }\end{array}$ \\
\hline & & & & Guest Speaker & & \\
\hline \multicolumn{7}{|c|}{ 3) Marketing } \\
\hline $\begin{array}{l}\text {-increase the enrollees } \\
\text { of the school. }\end{array}$ & $\begin{array}{l}\text {-Training on } \\
\text { Organizing and } \\
\text { Effective School } \\
\text { Campaign/ } \\
\text { Marketing } \\
\text { Strategies }\end{array}$ & $\begin{array}{l}\text {-Establish } \\
\text { program goals }\end{array}$ & $\begin{array}{l}\text { Summer, } \\
2022 \text {. }\end{array}$ & $\begin{array}{c}\text { School } \\
\text { Administrators }\end{array}$ & $\begin{array}{c}\text {-Financial } \\
\text { Resources/ } \\
\text { Budget }\end{array}$ & $\begin{array}{l}\text {-Increased the } \\
\text { enrollees of the } \\
\text { school. }\end{array}$ \\
\hline
\end{tabular}




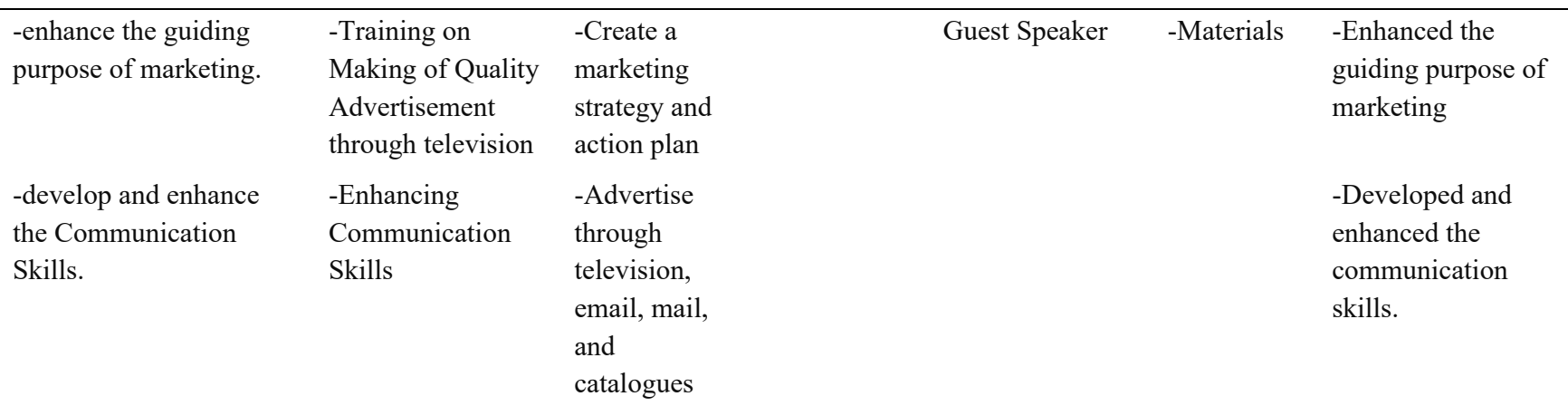

If you finance your career, you will need to know something all about three areas of financial management; you a knowledge of finance to make many personal decisions; and virtually all business decisions have financial implication important decisions are generally made by teams from the accounting, finance, legal, marketing, personnel, and production departments (Brigham and Houston, n.d). In strategic financial management, three types of management are considered: investment strategy management, the financial provision and ultimately the profitability and the optimal combination of these three strategy kinds and its optimum management, will encompass the financial success of an organization (Delkhosh \& Mousavi, 2016).

Training programs for employees often suggest both computer-related content and modules, which aim at improving the participants' self-efficacy concerning working in today's job market (Mor, Laks, \& Hershkovitz, 2016). Abushugair, Aqel, Abuseada (2015) suggest four main skills of the computer training programs to work improving the performance of staff, and were as follows; word processing, spreadsheets, presentations, internet, and e-mail.

One of the ways to realize increase school enrolment is to run such an excellent operation, that parents and students will be very satisfied with the academic programs and the impact will be seen in students' high academic achievement. In other words, it is operating the school business at a higher level than the regular school organization norms and effectively communicating the improvement to customers (Oplatka \& Brown, 2006). Omboi and Mutali (2011) state that a well-executed direct advertising campaign can offer a positive return on investment through increased student enrolment. They maintained that direct advertising communicates the product offers, service, or event; and explains how to get the offered product, service, or event. This tool utilizes email, mail, catalogs, encourage direct responses to radio and $\mathrm{TV}$, in order to reach targeted audiences to increase sales and test new products and alternate marketing tactics. Television is generally acknowledged as the most powerful advertising medium and reaches a broad spectrum of consumer, however, needs to be adopted by educational institutions in reaching their target prospects and enrollees.

\section{Conclusions}

Managerial skills are the knowledge and ability of the individuals in a managerial position to fulfill some specific management activities or tasks. This knowledge and ability can be learned and practiced. Every school administrator can become better in management when they will learn and practice the behaviors, methods, and techniques of other successful school administrators. If they do other successful managers do, they will soon get the results that other successful managers get.

\section{Recommendations}

Based on the findings, the following recommendations are presented:

1. The secondary school administrators must practice the three managerial skills, which are conceptual, human skills, and technical skills.

2. The secondary school administrators should enhance their managerial skills in terms of conceptual skills, human skills, and technical skills by conducting seminars and workshops in line with their insufficient skills.

3. The secondary school administrators must develop in planning, communicating, decision-making, and problem solving, and motivating which are very important in school administration.

4. Teachers should also be allowed to attend related seminars and conferences to further develop their knowledge of these managerial skills and apply them to the workplace. 
5. The secondary school administrators should enhance their management and leadership skills for the delivery of good services in school administration.

6. The school administrators should strengthen their negotiation for resources and other support to achieve their goals.

\section{Acknowledgment}

The author wished to express her deepest appreciation to her research advisor, Dr. Mark Anthony Pa-alisbo and co-advisor, Assoc. Prof. Dr. Suphak Pibool for their support, patience, and encouragement throughout her graduate studies. She also extends her sincerest gratitude to the research committee headed by the chairman /external assessor, Dr. Pragob Kunarak; panel members; Dr. Vichian Puncreobutr, Dr. Annop Phothisuk, Dr. Nongnuch Suwanaruji, and Dr. Panida Klosawakdi for their innumerable insights on the workings of this research in general.

\section{References}

Abbass, I. M. (2012). Management Skills Tools for Leadership Imperatives in Democracy. European Scientific Journal, 8(16). ISSN: 1857-7881.

Abushugair, M., Aqel, M., \& Abuseada, A. (2015). The Impact of a Computer Training Program on the Ministry of Education and Higher Education Staff to Improve Computer Skills and Productive Performances. International Journal of Academic Research in Business and Social Sciences, 5(6), 423-441. https://doi.org/10.6007/IJARBSS/v5-i6/1697

Afshari, M., Honari, H., Qafouri, F., \& Jabari, N. (2012). Prioritizing managerial skills based on Katz's theory in physical education offices of universities in Iran. World Applied Sciences Journal, 20(3), 388-394.

Allison Partners. (2000). Approach: Strategy Articulation. Allison Partners. Retrieved from $\mathrm{http} / / / \mathrm{www}$. allisonpartners.com/services/strategy_articulation/

Amadi, D. C. (2019). Offical Writing/Correspondence. Federal University of Technology Owerri. Vocabulary Development, 36-40.

Berman, E. M., West, J. P., Richter, J., \& Maurice, N. (2002). Workplace relations: Friendship patterns and consequences. Public Administration Review, 62, 217-230. https://doi.org/10.1111/0033-3352.00172

Brealey, R., Myers, S., \& Allen, F., (2006). Working Capital Management. Corporate Finance. The McGraw-Hill Companies (10th Ed.), 13-832.

Brigham, E., \& Houston, J. (nd). Fundamentals of Financial Management (10th ed.). Retrieved from https://www.academia.edu/31830841/Fundamentals_of_Financial_Management_10th_Edition_

Bush, T., Middlewood, D., \& Briggs, A. (2006). The Impact of School Leadership Development: Evidence from the 'new visions' Programme for Early Headship. Journal of In-Service Education, 32, 185-200. https://doi.org/1080/13674580600650948

Crabtree, S. (2004). Getting personal in the workplace: Are negative relationship squelching productivity in your company? Gallup Management Journal, June, 1-4.

Cronje. G. J., De, J., Du, T. Gawie, S., \& Motlatla, M. D. C. (2004). Introduction to Business Management (6th ed.). Oxford University Press: Southern Africa.

Dana, D. (2001). Conflict Resolution. Sydney: McGraw Hill.

Delkhosh, M., \& Mousavi, H. (2016). Strategic Financial Management Review on the Financial Success of an Organization. Mediterranean Journal of Social Sciences MCSER Publishing, Rome-Italy, 7(2), 30-34. https://doi.org/10.5901/mjss.2016.v7n2s2p30

Dubey, N. K. (2018). The Importance and Scope of Technical Writing Skills. The IUP Journal of English Studies, $X I I(1), 28-31$.

Eisenhardt, K., \& Martin, J. A. (2000). Dynamic Capabilities: What Are They? Strategic Management Journal, Special Issue 21, 1105-1121.

Ellingwood, S. (2004). The collective advantage, Retrieved June, 2010 from http://www.gallupjournal.com/GMJarchieve/issue3/2001915c,asp

Fapohunda, T. (2013). Towards Effective Team Building in the Workplace. International Journal of Education and 
Research, 1(4), 1-12.

Gilboa, I. (2011). Rational choice. Cambridge, MA: MIT Press.

Goodarzi, M. (2002). The Framework of Managerial Skills (Technical, Human, Conceptual) in the Management of Physical Education Organization in Iran. A dissertation Presented in Partial Fulfillment of the Requirements for the Degree of Doctrine in Sport Management. Tarbiat Modares University, Tehran, Iran.

Goodarzi, M., Nazari, R., \& Ehsani, M. (2012). Presenting the Structural Equation Model of Effecting of Communication Skills on Managerial Skills of Sports Administrators. Applied Research in Biological Science in Sports Management, 1, 11-20.

Graham, S., Bollinger, A., Booth Olson, C. D., Aoust, C., MacArthur, C., McCutchen, D., \& Olinghouse, N. (2012). Teaching writing in elementary school: A practice guide. Washington, DC: National Center for Education Evaluation and Regional Assistance, Institute of Education Sciences, U.S. Department of Education.

Grobler, P., Warnich, S., Carrell, M., Elbert, N., \& Hatfield, R. (2002). Human resource management in South Africa. Cornwall: Thomson, Pat bond, London.

Gronn, P. (2002). Distributed leadership. In Second International Handbook of Educational Leadership and Administration. Edited by Kenneth Leithwood and Phillip Halliger. Dordrecht: Kluwer Academic Publishers, 653-696. https://doi.org/10.1007/978-94-010-0375-9_23

Gronn, P. (2009). From distribute to hybrid leadership practice. In Distributed Leadership. Different Perspectives. Edited by Alma Harris. London: Springer, 197-218. https://doi.org/10.1007/978-1-4020-9737-9_11

Hall, F. (2013). The Importance of Strategic Planning. Retrieved from https://www.researchgate.net/publication/241688503_The_Importance_of_Strategic_Planning

Harris, A. (2014). Distributed Leadership Matters: Perspectives, Practicalities, and Potential. Thousand Oaks: Corwin. https://doi.org/10.4135/9781483332574

Kahn, D., \& Kahn, R. (nd). The Social Psychology of Organizations (2nd ed.). New York, NY: Wiley.

Katz, R. (1974). Skills of an Effective Administrator. Harvard Business Review, 52, 90-102. https://doi.org/10.2307/41164516

Kheirmand, M., Lotfi, H., \& Etebarian, A. (2012). Study the Relationship Between Management Skills of Agricultural Bank Managers of Esfahan Province with The Performance of The Branches. Quarterly Journal of Management and Development Process, 25(3), 93-119.

Kotler, P., \& Keller, K. L. (2006). Marketing Management (12th ed.). Prentice Hall: London.

Mor, D., Laks, H., \& Hershkovitz, A. (2016). Computer skills training and readiness to work with computers. Interdisciplinary Journal of e-Skills and Life Long Learning, 12, 95-112. https://doi.org/10.28945/3451

Moradi, M., Jafari, A., \& Omidi, A. (2013). A Modeling the Impact of Transformational Leadership on Organizational Citizenship Behavior and Organizational Justice Youth and Sports Ministry of the Islamic Republic of Iran. Sport Management, 4, 124-107.

Msila, V. (2012). Conflict Management and School Leadership. Journal of Communication, 3, $25-34$. https://doi.org/10.1080/0976691X.2012.11884792

Nazari, R. (2017). The Impact of Mental Skills on Management Skills and Selecting Management Models on Sports Managers. International Journal of Science and Sport, 24, 124-133. https://doi.org/10.14486/IntJSCS658

Nazari, R., Ghasemi, H., \& Sohrabi, Z. (2016). The Relationship Between Communication Skills, Leadership Styles, and Culture and the Effectiveness of Managers in Sports Organizations: Structural Equation Modeling. Journal of Sport Management and motor behavior, 21, 102-93. https://doi.org/10.14486/IntJSCS658

Omboi, B. M., \& Mutali, J. N. (2011). Effect of selected marketing communication tools on student enrolment in private universities in Kenya. European Journal of Business and Management, 3(3), 172-205.

Oplatka, I., \& Brown, J. H. (2006). Universities in a Competitive global Marketplace. International Journal of Public Sector Management, 19(4), 316-338. https://doi.org/10.1108/09513550610610669176

Pinto, C. (2018). Focus on Professional Development in Higher Education Institutions. ASEAN Journal of Management and Innovation, 5, 1-14. https://doi.org/10.14456/ajmi.2018.1

Piot, L., \& Kelchtermans, G. (2016). The Micropolitics of Distributed Leadership: Four Case Studies of School 
Federations. Educational Management Administration \& Leadership, 44, 632-649. https://doi.org/10.1177/1741143214559224

Reitzug, U. C. (2002). School Reform Proposals: The Research Evidence. Retrieved from http://www.asu.edu/educ/epsl/ERPU/d ocum ents/ERPU\%202002-01/Chapter\%2012-Rei

Salehi, H., Mohammadi, F., \& Mohammadi, H. (2014). Relationship between Management Skills and Customer Experience Management. Indian Journal of Science and Research, 7(1), 626-634.

Sharma, V. (2019). Importance of Having Computer Skills in Today's World. Klient Solutech: Grow your Business and Leadership Skills. Retrieved from http://www.klientsolutech.com/importance-of-having-computer-skills-in-todays-world/

Song, S., \& Olshfski. (2008). Friends at work: A comparative study of work attitudes in Seoul City Government and New Jersey State. Administration \& Society, 40(2), 147-169. https://doi.org/10.1177/0095399707312827

Torki, A., Shouriche, M. H., \& Meshgati, M. R. (2011). Study of Manager's Stress: Political Skills and Escape from the Pressures of Management Letters. Management Development, 90, 45-49.

Wahlstrom, T. (no year). Why is Managing Conflict so Important? OTAVALA Consulting. Retrieved from http://otavala.com/yahoo_site_admin/assets/docs/Why_is_Managing_Conflict_so_Important.6075405.pdf

Weadon, D. (2014). Management Reporting: Effective Organizational Data Processes. RSM International. Retrieved from

https://rsmus.com/what-we-do/services/management-consulting/management-reporting-implementing-effectiveorganizational-data.html

Xaba, M. (2006). The Difficulties of School Development Planning. South African Journal of Education, 26(1), $15-26$.

Xiaojuan, Z. (2010). Study on the Management of Informal Organization in Firms. International Conference on Information Management, Innovation Management and Industrial Engineering, Kunming, 318-321. https://doi.org/10.1109/ICIII.2010.82

Yukongdi, V. (2010). A Study of Thai Employees' Preferred Leadership Style. Asia Pacific Business Review, 16(1-2), 161-181. https://doi.org.10.1080/13602380903168962 